Int Journal Of Health Manag. And Tourism 2020, 5(2), 123-144

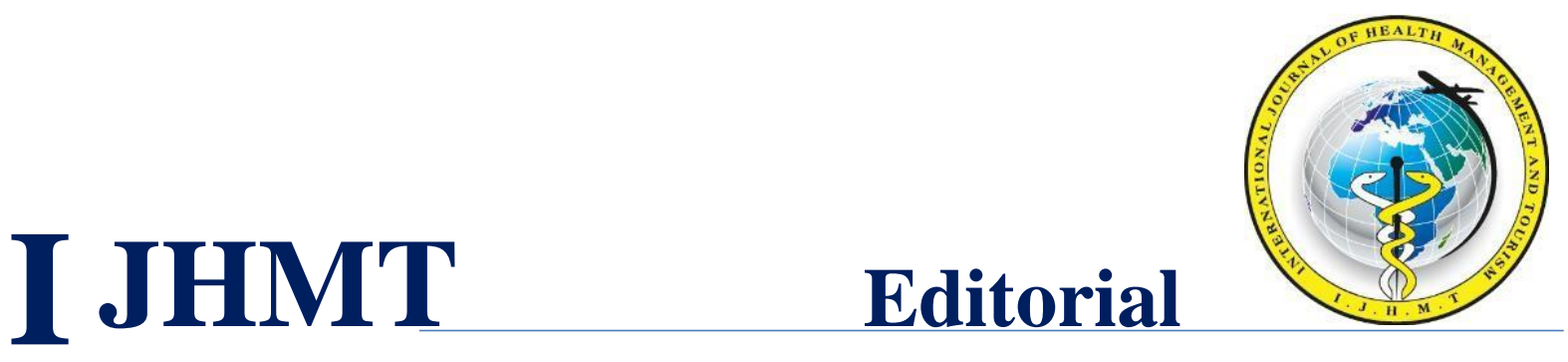

International Journal Of Health Management And Tourism

\title{
THE RELATIONSHIP BETWEEN PERCEIVED ETHICAL LEADERSHIP, ORGANIZATIONAL JUSTICE, AND TURNOVER INTENTION AMONG GENERAL HOSPITAL NURSES
}

\author{
Nükhet Bayer* , İsmet Şahin ** \\ * Faculty Member Asst. Prof. Lokman Hekim University, Health Sciences Faculty, Nursing Department \\ nukhetbayer@yahoo.com \\ ORCID Number: 0000-0003-3177-0596
}

\author{
**Prof.Dr., Lokman Hekim University, Health Services Vocational School \\ ismet.sahin@lokmanhekim.edu.tr \\ ORCID Number: 0000-0003-0878-5669 \\ Received: 11.05 .2020 \\ Accepted: 31.08 .2020 \\ Research Article
}

\section{Abstract:}

This study aims to was to investigate the relationship between perceived ethical leadership, organizational justice, and turnover intention among nurses. The research was conducted in a general-purpose private hospital in Ankara. The subjects of the study consist of all nurses working in the private hospital, and the sample consisted of 234 nurses who agree to participate in the study voluntarily. After the necessary permissions were obtained, the data were collected with a structured data collection tool based on the factual and behavioral attitude measurement consisting of personal information form, ethical leadership, organizational justice and turnover intention scales. The scores of the nurses' ethical leadership and organizational justice scales were above average, however, the score of turnover intention scale was below the average. While there was a strong linear positive relationship between ethical leadership and organizational justice, there was a linear negative medium level relationship between organizational justice and turnover intention. There was a linear negative and significant relationship between ethical leadership and turnover intention. The study concludes that ethical leadership will increase the perception of justice in the organization and reduce turnover intention amongst nurses. 


\section{INTRODUCTION}

Despite the scarce resources in the provision of health services, providing high quality services is considered as an important success factor in the health sector in the face of the increasing number of hospitals and a competitive environment. The pursuit of excellence in service is a strategy, and nurses have a significant impact on the evaluation of the patientcentered care service and the long-term success of hospitals. The behavior of the nurses has critical implications for hospitals, thus maintaining an adequate nursing workforce has become both a national and international priority ( Zhang, Li, Gong, \& Xu, 2019). Organizational commitment is a psychological condition that defines the relationship between employees and the organization and can affect employees' decisions to work or not to work in the organization (Cao, Liu, Liu, Yang, \& Liu, 2019).

Since nurses play a very significant role in the health care system, it is important to figure out the causes of the turnover rate of nurses. There are studies in the literature that determines why and how nurses leave their jobs (Tummers, Groeneveld, \& Lankhaar, 2013). Mobbing, negative work environments, and low organizational justice are among the reasons for turnover in the health sector (Huang, Li, \& Wan, 2019). However, there are limited studies in the literature examining the effect of organizational justice perception and ethical leadership, an important factor in the formation of this perception (Barkhordari-Sharifabad, Ashktorab, \& Atashzadeh-Shoorideh, 2017), on turnover intention among nurses. From this point of view, the study examines the impact of ethical leadership on organizational justice and turnover intention.

\section{BACKGROUND}

This section describes the theoretical framework of the variables discussed in the research to understand the impact of the organizational justice, which defines the perception of nurses working in health institutions about whether they are treated fairly, and ethical leadership behaviors of managers, who play an important role in the development of personal attitudes and behaviors, on turnover intentions of employees. 


\subsection{Ethical Leadership}

Ethical leadership exhibits normatively appropriate behavior, focusing on personal actions and interpersonal relationship, and the promotion of such behavior to followers using mutual communication, augmentation, and decision making". An ethical leader is someone who reacts to any mistake within the organization and tries to prevent it. Ethical leadership behavior plays an important role in developing employees' attitudes and behaviors (Brown, Treviño, \& Harrison, 2005). The purpose of ethical leadership is to clarify and present the ethical dimensions that exist in every administrative decision and to establish ethical principles that guide the decision-making process in organizations. Leaders with ethical leadership qualities establish a positive relationship based on respect and trust with the people around them, guide them with his/her attitudes and interactions, and positively influence the followers.

Nurses' service provision and care for patients express useful behaviors and can be defined as patient-oriented ethical behavior. Ethical leadership engages nurses in consists of creating and supporting a convenient environment for providing good quality and efficient health services, as well as providing ethical behavior to individuals (Barkhordari-Sharifabad et al., 2017). Therefore, ethical leadership is assumed to be able to provide positive and desired changes in the nursing profession (Gagné \& Deci, 2005). Ethical leadership behavior has many positive consequences such as employee performance, trust to the leader, intrinsic motivation, job satisfaction, and emotional commitment (Cheng, Chang, Kuo, \& Cheung, 2014). Ethical leadership is known to be positively associated with the psychological wellbeing of the professional care team, which positively reflects patients' perceptions of the quality of nursing (Gillet et al., 2018). There are studies indicating that ethical leadership enables employees to develop fiduciary relationships with their managers, thereby leading to low levels of burnout while ensuring a high level of employee participation (Brown et al., 2005; Gillet et al., 2018). Many studies on ethical leadership have revealed that ethical leadership has positive behavioral results that will reflect on organizational performance. However, there is also a deficit in the nursing management literature regarding the behavioral consequences of ethical leadership for keeping or quitting the job (Islam, Ahmed, \& Ali, 2019). 


\subsection{Organizational Justice}

Organizational justice Colquitt et al.(2001) have defined organizational justice as the subjective perceptions of people of fairness in organizations. Generally, organizational justice can be classified into three types including procedural, distributive, and interactional justice. Distributive and procedural justice are often perceived as the structural forms of justice that focus on the organization. On the other hand, interactional justice is considered as the interactional form of justice that focus on the manager or the supervisor ((Loi, Yang, \& Diefendorff, 2009). Organizational justice is the process of evaluating managerial decisions for variables such as the distribution of employees' duties, compliance with overtime, empowerment of employees, wage level, and reward distribution. Thus, organizational justice can be defined as employees' positive perception toward the managers' decisions and practices about the organization and employees. In the literature, organizational justice includes three sub-dimensions: distributional, procedural, and interactive justice (Colquitt et al., 2001). These dimensions are briefly explained as follows:

Distributional Justice: It means that the distribution of the decisions taken in organizations is fair and all kinds of gains such as wages and reward promotions are perceived fairly by employees.

Procedurall Justice: It refers to the fair perception of the decision-making processes of distribution made within the organization by the employees. It is of great importance for the employees to adopt these decisions, as they approve these operations are fairly made.

Interactive Justice: It includes behaviors such as valuing employees, treating them with respect, and disclosing a decision defined as social value to employees. It refers to disclosing of the processes related, to the decision-making by the managers to be honest and transparent toward the employees.

Organizational justice also covers moral and ethical evaluations of managerial behavior (Imamoglu, Ince, Turkcan, \& Atakay, 2019). It has also been found to be very influential on workers' health (Elovainio et al., 2005). Low organizational justice has been found to be associated with psychological disorder, insomnia, cardiovascular death, and low rates of personal health (Heponiemi et al., 2007). It has been determined that the performed applications are fairly evaluated by the employees if a decision is applied duly, that is, if the 
procedures are applied consistently in accordance with the common interests, ethical and ethical rules of all parties, based on the correct information without the benefit of a particular person (Brockner et al., 1994).

Justice is the most promising approach to improve motivation and performance in the workplace and to ensure peace among the employees. The reason for the feeling of revenge is the feeling of injustice. The injustice when felt can turn into aggression or another way of harming the target (Jawahar, 2002). The perception of justice in the organization affects not only employees' beliefs, emotions, attitudes and behaviors, but also their esteem and social identities (Elovainio et al., 2005).

\subsection{Turnover Intention}

As in all countries of the world, the shortage of nurses in Turkey is also of great importance. According to the Ministry of Health's 2018 data, the number of nurses per 100,000 people is 301 while the OECD average is 938, 1823 in Norway, and 1755 in Switzerland. For the number of nurses per person among OECD countries, Turkey is listed in the last rows ( $\underline{\mathrm{SB}}$ 2019). In Turkey, 73\% of nurses are employed in the medical institutions that are bound to the Ministry of Health, $12 \%$ in the university hospitals, and $15 \%$ in the medical institutions bound to private sector. Personnel expenditures constitute $45-60 \%$ of total expenditures of health institutions. Organizations spend a significant part of their budget to hire and train new employees (Holtom, Mitchell, Lee, \& Eberly, 2008). The costs of low of a level of commitment to work, disruption of daily work, emotional stress and excessive workload on rest of the employees in the organization aren't easy to be under debate in monetary terms. The number of staff leaving the job may result in a negative for the organization both internally and externally (Singh \& Loncar, 2010).

There are many organizational and individual factors that cause nurses to turnover. Organizational variables include poor working environment, work stress, workload, and insufficient career opportunities, while age, gender, working house, etc are among the individual factors. (Staggs \& Dunton, 2012). In addition to these, the other factors of turnover intention are the limited leadership support of nurse managers on employees, intimidation from the work, mobbing, harassment and negative relationships with other nurses or other health personnel (Hayward, Bungay, Wolff, \& MacDonald, 2016). This study provides 
evidence to healthcare administrators and policy makers to raise the number of nurses per person at an appropriate level and to prevent experienced nurses from leaving the job.

The objective of the research was to investigate the relationship between perceived ethical leadership, organizational justice, and turnover intention among nurses that working in a special general hospital of Turkey. For the aim of the research, the following hypotheses have been established:

- A significant difference will be found in organizational justice perception, organizational environment and turnover intention among the different variables participants' characteristics (age, gender, working hours, etc.).

- Perceived ethical leadership will have a positive influence for the turnover intentions of nurses.

- Perceived organizational justice dimensions (interactive, procedural, and distribution justice) will have a positive influence for the turnover intentions of nurses.

\section{METHODS}

\subsection{Subjects}

The subject of the study consists of nurses working in a general-purpose private hospital in Ankara. It was aimed to reach all of the subject. Purpose sampling method was applied in the study, though. The subjects of the study were male and female nurses of at least 1 year experience and volunteered to participate.

\subsection{Measures/Instruments}

The research data were collected by using the form developed by the researchers to determine the factual (individual and professional) characteristics of nurses, and the scales of ethical leadership, organizational justice, and turnover intention were also used.

Ethicall leadership scale: Ethical leadership was measured using the 10 items ELS scale developed by Brown et al (2005), then adapted to Turkish by Tuna et al. (2012) and validity and reliability survey has been done. Ethical leadership consists of 10 items created on the 
Likert scale. Ethical leadership of their immediate supervisor was rated by the respondents, using a five item Likert scale (where $1=$ strongly disagree and $5=$ strongly agree).

Organizational justice scalle: "Organizational Justice Scale" developed by Niehoff was applied by Moorman (1993). The scale, which was translated and adapted into Turkish by Polat (2007), consists of a total of 20 items in the five-point Likert scale. Among the items in the scale, the first 9 expressions measure interactive justice, expressions 10-15 measure procedural justice, and expressions 16-20 measure distribution justice.

Turmover intention scale: Turnover intention scale was developed by Cammann et al (1983) and adapted to Turkish and used Mimaroğlu (2008). Three items were adapted to measure turnover intentions from prior research and the scale consists of 3 items in five-Likert style.

For the research, approval was obtained from the Ethics Committee of Non-Invasive Clinical Researches from Lokman Hekim University. Written permission was obtained from the hospital administrations where the study was conducted. Nurses who were invited to the study were informed about the research, and the data collection tool were distributed to the volunteers by the researcher, then the data collection forms were collected in an appropriate time.

\subsection{Data Collection and Analysis}

The data collection tool used in the study was distributed to the nurses working in the hospital, who volunteered to participate in the research, by the researchers between September and November 2019. The questionnaire was given to each nurse separately to get enough feedback from the nurses. They were required to read the instructions very carefully and were encouraged to ask questions where unclear. After the administrations, the questionnaires were immediately collected from the participants. Missing incorrect and empty data were excluded and data were collected from a total of 234 people.

The analysis of the research was conducted by using SPSS 22 statistical software. Variables that are not normally distributed are expressed as median (minimum and maximum) values. When comparing scale attitude averages according to individual and professional characteristics of nurses, Mann Whitney $U$ test was used for the comparison of two independent groups, while Kruskal-Wallis Variance analysis was used for more than two group comparisons. $\mathrm{P}<0.05$ was accepted for statistical significance. 


\subsection{Limitations}

This study had some limitations. First, since this study was only one of general-purpose private hospital in Ankara, Turkey, this might lead to restricted generalsability. Second, although subjects were informed that investigation was anonymous and the result will be confidential from their leaders, they might still have some concerns to express their most honest thoughts, which might induce some bias.

\subsection{Reliability of the Data Collection Tool}

The reliability coefficients of the scales used in the research are given.Table 1 shows the Cronbach Alpha values of ethical leadership, organizational justice and turnover intention scales. Organizational Justice and its sub-dimensions have high reliabilities $(0.940,0.903$, 0.926, 0.944, respectively). The ethical leadership scale Cronbach Alpha coefficient is 0.962 and has high reliability. The Cronbach Alpha coefficient of turnover intention scale is 0,761 and its reliability is very high.

Table 1- Ethical leadership, Organizational Justice, and Turnover Intention Reliability Coefficient $(\mathrm{N}=234)$

\begin{tabular}{lcc}
\hline Scales & Cronbach Alfa & No. of Items \\
\hline Organizational Justice & 0.940 & 20 \\
Interactive Justice & 0.903 & 9 \\
Procedural Justice & 0.926 & 6 \\
Distribution Justice & 0.944 & 5 \\
Ethical leadership & 0.962 & 10 \\
Turnover Intention & 0.761 & 3 \\
\hline
\end{tabular}

\section{Findings}

Table 2 presents the demographic characteristics of the sample. A total of 234 participants finished the questionnaires. Most of them were female $(77.78 \%)$ and single $(59.83 \%)$. And $43.59 \%$ of nurses got a health vocational high schools (HVHS) graduates, and the mean age of participants was 27.25 ( $\mathrm{SD}=6.16)$. When the education level of nurses is examined, there 
are health vocational high schools (HVHS) graduates (43.59\%), associate degree $(23.08 \%)$, bachelor (29.91\%) and post-graduate (3.42\%). $11.11 \%$ of the nurses work in an emergency, $11.97 \%$ in the operating room, $25.64 \%$ in surgery, $30.77 \%$ in internal medicine and $20.51 \%$ in the intensive care unit.

Table 2- Descriptive statistics of socio-demographic information of individuals participating in the study

\begin{tabular}{lrr}
\hline Variables & Number (n) & Percentage (\%) \\
\hline Gender & & \\
Male & 52 & 22.22 \\
Female & 182 & 77.78 \\
Marital Status & & \\
$\quad$ Married & 94 & 40.17 \\
Single & 140 & 59.83 \\
Age & & $27.25 \pm 6.16$ \\
Education Level & & \\
HVHS & 102 & 43.59 \\
Associate's Degree & 54 & 23.08 \\
Bachelor Degree & 70 & 29.91 \\
Postgraduate Degree & 8 & 3.42 \\
Working Unit & & \\
Emergency & 26 & 11.11 \\
Operating room & 28 & 11.97 \\
Surgery & 60 & 25.64 \\
Internal medicine & 72 & 30.77 \\
Intensive care & 48 & 20.51 \\
Job Duration & & \\
1-3 year & 80 & 34.19 \\
4-6 year & 62 & 26.50 \\
7-9 year & 34 & 14.53 \\
10-12 year & 36 & 15.38 \\
13 year and above & 22 & 9.40 \\
\hline TOTAL & $\mathbf{2 3 4}$ & $\mathbf{1 0 0 . 0 0}$ \\
\hline
\end{tabular}

Table 3 shows the nurses' ethical leadership, organizational justice, subdimensions, and turnover intention scale mean scores. Descriptive statistics regarding the scale scores are given in Table 3. Organizational justice scale mean score was $3.59 \pm 0.76$, interactive justice subscale score average was $3.14 \pm 0.87$, procedural justice subscale point average was $3.96 \pm$ 0.92 , and distribution justice subscale point average was $3.99 \pm 0.97$. The ethical leadership scale mean score was $33.33 \pm 10.65$, and the mean score of turnover intention was $6.96 \pm$ 2.85 . 
Table 3 - Distribution of Nurses' Ethical Leadership, Organizational Justice, Sub-Dimensions and Turnover Intention Scale Mean Scores

\begin{tabular}{lrcrr}
\hline Variables & Mean & Std.Dev. & Min. & Max. \\
\hline Organizational Justice & 3.59 & 0.76 & 1.70 & 5.00 \\
Interactive Justice & 3.14 & 0.87 & 1.11 & 5.00 \\
Procedural Justice & 3.96 & 0.92 & 1.17 & 5.00 \\
Distribution Justice & 3.99 & 0.97 & 1.20 & 5.00 \\
Ethical leadership & 33.33 & 10.65 & 10.00 & 50.00 \\
Turnover Intention & 6.96 & 2.85 & 3.00 & 14.00 \\
\hline
\end{tabular}


Table 4- Organizational Justice, Ethical Leadership and Turnover Intention Scale Score Mean According to the Socio-demographic Characteristics of Individuals $(\mathrm{N}=234)$

\begin{tabular}{|c|c|c|c|c|c|c|c|c|c|c|c|c|}
\hline \multirow[b]{2}{*}{ Variables } & \multicolumn{2}{|c|}{ Organizational Justice } & \multicolumn{2}{|c|}{ Interactive justice } & \multicolumn{2}{|c|}{ Procedural Justice } & \multicolumn{2}{|c|}{ Distribution Justice } & \multicolumn{2}{|c|}{ Ethical Leadership } & \multicolumn{2}{|c|}{ Turnover Intention } \\
\hline & Mean \pm S.D & $\begin{array}{l}\text { Test value } \\
\text { and } \mathrm{p} \text { value }\end{array}$ & Mean \pm S.D & $\begin{array}{l}\text { Test value } \\
\text { and } \mathrm{p} \text { value }\end{array}$ & Mean \pm S.D & $\begin{array}{l}\text { Test value } \\
\text { and } p \text { value }\end{array}$ & Mean \pm S.D & $\begin{array}{l}\text { Test value } \\
\text { and } \mathrm{p} \text { value }\end{array}$ & Mean \pm S.D & $\begin{array}{l}\text { Test value } \\
\text { and } \mathrm{p} \text { value }\end{array}$ & Mean \pm S.D & $\begin{array}{c}\text { Test value } \\
\text { and } \mathrm{p} \text { value }\end{array}$ \\
\hline \multicolumn{13}{|l|}{ Gender } \\
\hline Male & $3.55(2.75-5.00)$ & $\begin{array}{l}\mathrm{z}=-1.106 \\
\mathrm{p}=0.269\end{array}$ & $3.11 \pm 0.83$ & $\begin{array}{l}\mathrm{t}=-0.286 \\
\mathrm{p}=0.775\end{array}$ & $4(3.17-5.00)$ & $\begin{array}{l}z=-2.666 \\
p=0.008\end{array}$ & $4.6(3.00-5.00)$ & $\begin{array}{l}\mathrm{z}=-\mathbf{2 . 4 4 3} \\
\mathrm{p}=0.015\end{array}$ & $31.5(14.00-50.00)$ & $\begin{array}{l}\mathrm{z}=-1.851 \\
\mathrm{p}=0.064\end{array}$ & $9(3.00-12.00)$ & $\begin{array}{l}\mathrm{z}=-0.211 \\
\mathrm{p}=0.833\end{array}$ \\
\hline Female & $3.7(1.70-5.00)$ & & $3.15 \pm 0.88$ & & $4(1.17-5.00)$ & & $4(1.20-5.00)$ & & $37(10.00-50.00)$ & & $6(3.00-14.00)$ & \\
\hline \multicolumn{13}{|l|}{ Marital Status } \\
\hline Married & $3.54 \pm 0.78$ & $\begin{array}{l}\mathrm{t}=-0.972 \\
\mathrm{p}=0.332\end{array}$ & $3.22(1.11-5.00)$ & $\begin{array}{l}\mathrm{z}=-1.626 \\
\mathrm{p}=0.104\end{array}$ & $3.83(1.83-5.00)$ & $\begin{array}{l}\mathrm{z}=-2.543 \\
\mathrm{p}=\mathbf{0 . 0 1 1}\end{array}$ & $4(1,60-5,00)$ & $\begin{array}{l}\mathrm{z}=-\mathbf{2 . 6 8 0} \\
\mathrm{p}=\mathbf{0 . 0 0 7}\end{array}$ & $32,26 \pm 12,74$ & $\begin{array}{l}\mathrm{t}=-1.188 \\
\mathrm{p}=0.237\end{array}$ & $6(3,00-14,00)$ & $\begin{array}{l}\mathrm{z}=-\mathbf{3 . 0 3 5} \\
\mathrm{p}=\mathbf{0 . 0 0 2}\end{array}$ \\
\hline Single & $3.64 \pm 0.74$ & & $3(1.11-5.00)$ & & $4.08(1.17-5.00)$ & & $4,4(1,20-5,00)$ & & $34,06 \pm 8,96$ & & $8(3,00-13,00)$ & \\
\hline Age & $r=-0.340 p$ & .001 & $r=-0.083 p=$ & $=0.207$ & $r=-0.405 p$ & 0.001 & $r=-0.469 p$ & .001 & $r=-0.356 p<0$ & 001 & $r=-0.005 p=$ & $=0.936$ \\
\hline \multicolumn{13}{|l|}{ Education Level } \\
\hline HVHS & $3.85^{\mathrm{a}}(1.85-5.00)$ & $K=25.146$ & $3.12 \pm 0.81$ & $F=4.120$ & $4.67^{\mathrm{a}}(1.83-5.00)$ & $K=29.163$ & $4.60^{\mathrm{a}, \mathrm{c}}(1.60-5.00)$ & $K=49.081$ & $35.26 \pm 9.76^{\mathrm{a}}$ & $F=9.991$ & $8(3.00-14.00)$ & $\mathrm{K}=3.339$ \\
\hline Associate's Degree & $3.75^{\mathrm{b}}(1.85-5.00)$ & $\mathbf{p}<0.001$ & $3.42 \pm 0.88^{\mathrm{a}}$ & $\mathrm{p}=0.017$ & $4.00^{\mathrm{b}}(1.83-5.00)$ & $\mathrm{p}<0.001$ & $4.00^{\mathrm{b}, \mathrm{c}}(1.60-5.00)$ & $\mathbf{p}<0.001$ & $35.82 \pm 10.11^{\mathrm{b}}$ & $\mathrm{p}<0.001$ & $6(3.00-11.00)$ & $\mathrm{p}=0.188$ \\
\hline $\begin{array}{l}\text { Bachelor- } \\
\text { Postgraduate Degree }\end{array}$ & $3.20^{\mathrm{a}, \mathrm{b}}(1.70-4.85)$ & & $2.99 \pm 0.9^{\mathrm{a}}$ & & $3.67^{\mathrm{a}, \mathrm{b}}(1.17-5.00)$ & & $3.60^{\mathrm{a}, \mathrm{b}}(1.20-5.00)$ & & $29.1 \pm 10.99^{\mathrm{a}, \mathrm{b}}$ & & $6(3.00-12.00)$ & \\
\hline \multicolumn{13}{|l|}{ Working Unit } \\
\hline Emergency & $3.85(1.85-4.60)$ & & $3(1.11-4.11)$ & & $4.5(1.83-5.00)$ & & $4.2(1.60-5.00)$ & & $36(16.00-48.00)$ & & $7(3.00-11.00)$ & \\
\hline Operating room & $3.65(1.90-5.00)$ & $\mathrm{K}=3.005$ & $3.11(1.78-5.00)$ & $\mathrm{K}=2.757$ & $4(1.83-5.00)$ & $\mathrm{K}=3.942$ & $4.2(1.80-5.00)$ & $\mathrm{K}=3.685$ & $33.5(13.00-50.00)$ & $\mathrm{K}=3.891$ & $5(3.00-14.00)$ & $\mathrm{K}=7.448$ \\
\hline Surgery & $3.65(1.70-4.80)$ & $\mathrm{p}=0.557$ & $3(1.11-4.56)$ & $\mathrm{p}=0.599$ & $4(1.17-5.00)$ & $\mathrm{p}=0.414$ & $4(1.20-5.00)$ & $\mathrm{p}=0.450$ & $37(16.00-50.00)$ & $\mathrm{p}=0.421$ & $6(3.00-11.00)$ & $\mathrm{p}=0.114$ \\
\hline Internal medicine & $3.45(2.00-4.70)$ & & $3(1.56-4.67)$ & & $4(1.83-5.00)$ & & $4.2(2.60-5.00)$ & & $32(10.00-50.00)$ & & $8(3.00-13.00)$ & \\
\hline Intensive care & $3.7(3.05-4.75)$ & & $3.22(2.22-5.00)$ & & $4(3.00-5.00)$ & & $4(2.40-5.00)$ & & $35(27.00-50.00)$ & & $9(3.00-12.00)$ & \\
\hline \multicolumn{13}{|l|}{ Job Duration } \\
\hline $1-3$ year & $3.95^{\mathrm{a}, \mathrm{c}}(1.70-4.85)$ & $K=45.596$ & $3.11(1.78-5.00)$ & $\mathrm{K}=11.551$ & $4.67^{\mathrm{a}, \mathrm{d}}(1.17-5.00)$ & $K=66.474$ & $4.70^{\mathrm{a}, \mathrm{d}}(1.20-5.00)$ & $\mathrm{K}=62.338$ & $38.00^{\mathrm{a}, \mathrm{c}}(13.00-50.00)$ & $K=39.420$ & $7(3.00-14.00)$ & $K=17.314$ \\
\hline 4-6 year & $3.90^{\mathrm{b}, \mathrm{d}}(2.65-5.00)$ & $\mathrm{p}<0.001$ & $3.44(1.11-5.00)$ & $\mathrm{p}=0.05$ & $4.50^{\mathrm{b}, \mathrm{e}}(3.00-5.00)$ & $\mathrm{p}<0.001$ & $4.60^{\mathrm{b}, \mathrm{e}}(2.40-5.00)$ & $\mathbf{p}<0.001$ & $37.00^{\mathrm{b}, \mathrm{d}}(17.00-50.00)$ & $p<0.001$ & $7.00^{\mathrm{a}}(3.00-12.00)$ & $\mathrm{p}=0.002$ \\
\hline 7-9 year & $3.85^{\mathrm{e}}(1.85-5.00)$ & & $2.89(1.11-5.00)$ & & $4.00^{\mathrm{c}, \mathrm{f}}(1.83-5.00)$ & & $4.60^{\mathrm{c}, \mathrm{f}}(1.60-5.00)$ & & $28(10.00-50.00)$ & & $7(3.00-11.00)$ & \\
\hline
\end{tabular}




\begin{tabular}{|c|c|c|c|c|c|c|}
\hline $10-12$ year & $2.95^{\mathrm{c,d}, \mathrm{e}}(1.85-4.80)$ & $2.78(2.00-4.56)$ & $3.17^{\mathrm{d}, \mathrm{ef}}(1.83-5.00)$ & $3.20^{\mathrm{d}, \mathrm{e}, \mathrm{f}}(1.60-5.00)$ & $25.00^{\mathrm{c}, \mathrm{d}}(10.00-49.00)$ & $9.00^{\mathrm{b}}(3.00-13.00)$ \\
\hline 13 year and above & $3.35^{\mathrm{a}, \mathrm{b}}(2.80-4.05)$ & $3.33(2.22-4.44)$ & $3.17^{\mathrm{a}, \mathrm{blc},(}(3.00-4.00)$ & $3.40^{\mathrm{a}, \mathrm{b}, \mathrm{c}}(2.00-4.00)$ & $25.00^{\mathrm{a}, \mathrm{b}}(16.00-43.00)$ & $4.00^{\mathrm{a}, \mathrm{b}}(3.00-$ \\
\hline
\end{tabular}

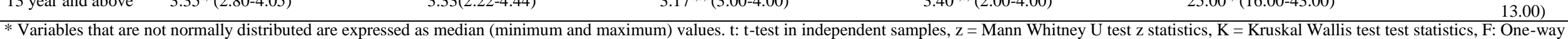
Variance Analysis F statistics

The group originating from the difference is expressed with the same letter index. 
When the ethical leadership, organizational justice and turnover intention according to some of the individual and professional characteristics of the nurses are considered, there was no significant difference in the scale and sub-dimensions concerning working units ( $>0.05)$. There is a significant difference in the scores of procedural justice and distribution justice sub-dimensions which are the sub-dimensions of organizational justice concerning gender $(\mathrm{p}<0.05)$. There was a significant difference in nurses' procedural justice and distribution justice, which are the sub-dimensions of organizational justice, and turnover intention concerning marital status $(\mathrm{p}<0.05)$. This difference was higher among single nurses than the married ones (procedural justice, distribution justice, and turnover intention scores) $(\mathrm{z}=-$ 2.543; $\mathrm{p}=0.011 ; \mathrm{z}=-2.680 ; \mathrm{p}=0.007 ; \mathrm{z}=-3.035 ; \mathrm{p}=0.002$, respectively).

While no linear relationship was found between age of the nurses and their interactive justice and turnover intention ( $p>0.05$ ), there is a relationship between their ages and total score of organizational justice scale, sub-dimensions of process justice, distribution justice and ethical leadership scale. There was a linear negative weak relationship between the age variable of the nurses and the organizational justice scale and the ethical leadership scale ( $r=-0,340$ $\mathrm{p}<0,001 ; \mathrm{r}=-0,356 \mathrm{p}<0,001)$, and there is a linear negative moderate relationship between their ages and procedural justice and distribution justice which are sub-dimensions of organizational justice $(r=-0,405 \mathrm{p}<0.001 ; \mathrm{r}=-0.446 \mathrm{p}<0.001)$.

There was a significant difference in terms of organizational justice scale scores according to the educational status of nurses $(\mathrm{K}=25,146 \mathrm{p}<0.001)$. There was a significant difference in terms of interactive justice mean scores, which is subdimension of organizational justice, according to the educational status of nurses $(\mathrm{F}=4,120 \mathrm{p}=0,017)$. The interactive justice subdimension score means of those with an associate degree $(3.42 \pm 0.88)$ are higher than the average score of those with a bachelor degree $(2.99 \pm 0.9)$. There is a statistical difference in terms of procedural justice sub-dimension according to the education level of the nurses $(\mathrm{K}=$ $9,163 \mathrm{p}<0.001)$. The median score of nurses with having a bachelor/post-graduate degree (3.67(1.17-5.00)) was lower than those of with HVHS/associate degree. And, distribution justice scale sub-dimension scores were significantly different $(K=29,163 \mathrm{p}<0.001)$. The median scores of the nurses having a HVHS, associate, bachelor and post-graduate education levels were found to be different from each other. There was a significant difference in terms of ethical leadership score averages according to educational status $(F=9,991 \mathrm{p}<0,001)$. The 
mean of ethical leadership scores $(29.1 \pm 10.99)$ of those who have a bachelor/post-graduate degree is lower than the mean of other education levels.

There was a significant difference in terms of organizational justice scale scores according to the job duration of the nurses $(\mathrm{K}=45,596 \mathrm{p}<0.001)$. The median score of nurses working for 1 3 years (3.95(1.70-4.85)) was higher than those of the median of 13 years and above (3.35(2.80-4.05)) and 10-12 years (2.95(1.85-4.80)). The median score of nurses working for 4-6 years (3.90(2.65-5.00)) was higher than those of the median scores of 13 years and above $(3,35(2,80-4,05))$ and $10-12$ years $(2,95(1,85-4,80))$. The median score of employees working for 7-9 years $(3.85$ (1.85-5.00)) was higher than the median score of employees working for 10-12 years (2.95 (1.85-4.80)).

There was a significant difference in terms of procedural justice scores, which is subdimension of organizational justice, according to the job duration of the nurses in the profession $(\mathrm{K}=66.474 \mathrm{p}<0.001)$, the median score of 1-3 years employees $(4.67(1.17-5.00))$ was higher than the median score of 13 years and above (3.17(3.00-4.00)) and 10-12 years (3.17(1.83-5.00)); the median score of employees working for 4-6 years (4.50(3.00-5.00)) was higher than the median score of 13 years and above (3.17(3.00-4.00)) and 10-12 years (3.17(1.83-5.00)); the median score of employees working for 7-9 years (4.00 (1.83-5.00)) was higher than the median score of 13 years and above (3.17(3.00-4.00)) and 10-12 years $(3.17(1.83-5.00))$.

There was a statistically noticeable difference in terms of distribution justice scores, which is sub-dimension of organizational justice, according to the job duration of the nurses in the profession $(\mathrm{K}=62,338 \mathrm{p}<0.001)$. The median score of nurses working for 1-3 years (4.70(1.20-5.00)) was higher than the median score of those who worked for 13 years and above (3.40(2.00-4.00)) and 10-12 years (3.20(1.60-5.00)). The median score of nurses working for 4-6 years (4.60(2.40-5.00)) was higher than the median score of 13 years and above (3.40(2.00-4.00)) and 10-12 years (3.20(1.60-5.00)), and median score of employees working for 7-9 years (4.60 (1.60-5.00)), was higher than the median score of 13 years and above (3.40(2.00-4.00)) and 10-12 year (3.20 (1.60-5.00)).

There was a statistically meaningful significant difference in terms of ethical leadership scale scores according to the job duration of the nurses in the profession $(K=39,42 \mathrm{p}<0,001)$. The median score of the nurses working for 1-3 years (38.00 (13.00-50.00)) was higher than the 
median score of those working for 13 years and over (25.00(16.00-43.00)) and 10-12 years (25.00(10.00-49.00)). The median score of 4-6 years employees (37.00(17.00-50.00)) was higher than the median score of those working for 13 years and above (25.00(16.00-43.00)) and 10-12 years $(25.00(10.00-49.00))$.

There was a measurable difference in terms of the scores of turnover intention according to the job duration of the nurses $(\mathrm{K}=17,314 \mathrm{p}=0,002)$. The median score of employees working for 4-6 years in the profession (7.00 (3.00-12.00)) was higher than the median of those working for 13 years and above (4.00 (3.00-13.00)); and the median score of employees working for 10-12 years $(9.00(3.00-13.00))$ was higher than the median score of those working for 13 years or more (4.00(3.00-13.00)).

Table 5- The relationship of variables with each other

\begin{tabular}{lcccccc}
\hline Variables & $\begin{array}{c}\text { Organization } \\
\text { al Justice }\end{array}$ & $\begin{array}{c}\text { Interactive } \\
\text { Justice }\end{array}$ & $\begin{array}{c}\text { Procedural } \\
\text { Justice }\end{array}$ & $\begin{array}{c}\text { Distribution } \\
\text { Justice }\end{array}$ & $\begin{array}{c}\text { Ethical } \\
\text { Leadership }\end{array}$ & $\begin{array}{c}\text { Turnover } \\
\text { Intention }\end{array}$ \\
\hline Organizational & 1.000 & & & & & \\
Justice & & & & & & \\
$\quad$ Interactive Justice & $\mathbf{0 . 7 9 9}$ & 1.000 & & & & \\
$\quad \begin{array}{l}\text { Procedural Justice } \\
\quad \text { Distribution Justice }\end{array}$ & $\mathbf{0 . 9 0 9}$ & $\mathbf{0 . 8 0 8}$ & $\mathbf{0 . 5 0 4}$ & 1.000 & & \\
Ethical Leadership & $\mathbf{0 . 7 6 7}$ & $\mathbf{0 . 6 6 9}$ & $\mathbf{0 . 6 7 7}$ & $\mathbf{0 . 5 5 3}$ & 1.000 & \\
& & & & & & \\
Turnover Intention & $\mathbf{- 0 . 4 9 4}$ & $\mathbf{- 0 . 5 9 0}$ & $\mathbf{- 0 . 3 5 6}$ & $\mathbf{- 0 . 1 9 1}$ & $\mathbf{- 0 . 4 0 3}$ & 1.000 \\
\hline p<0.05 was shown in dark color. & & & & & &
\end{tabular}

Table 5 shows the relationship be the scales with each other. There was a linear positive strong relationship between organizational justice and ethical leadership $(r=0.776 \mathrm{p}<0.05)$, whereas there was a linear negative medium level relationship between organizational justice and turnover intention $(\mathrm{r}=-0.494 \mathrm{p}<0.05)$. While there was a linear positive medium level relationship between interactive justice, one of the organizational justice scale subdimensions, and ethical leadership $(r=0.669 \mathrm{p}<0.05)$, there is a linear negative medium level relationship between interactive justice and turnover intention $(r=-0.590 \mathrm{p}<0,05)$. While there was a linear positive medium level relationship between procedural justice and ethical leadership $(r=0.677 \mathrm{p}<0.05)$, there is a weak linear negative relationship between procedural justice and turnover intention $(r=-0.356 \mathrm{p}<0.05)$. While there was a linear positive medium level relationship between distribution justice and ethical leadership $(r=0.553 \mathrm{p}<0.05)$, there 
was a weak linear negative relationship between distribution justice and turnover intention $(\mathrm{r}=-0.191 \mathrm{p}<0.05)$. There was a linear negative relationship between the ethical leadership scale and the turnover intention scale $(r=-0,403 \mathrm{p}<0.05)$.

\section{DISCUSSION}

Health care is provided in institutions that allow different professional groups to work together, which are structurally complex, where the division of labor and specialization is high, and that can provide services for twenty-four hours. Nurses are important in maintaining the existence of these institutions. The increasing complexity of health services, high pressure, demand and workload reduce nurses' level of job participation (Yin \& Yang, 2002). However, efficiency and quality of nursing in healthcare delivery is closely related to the performance of nurses ( . The results of the study, nurses have positive perceptions about organizational justice in the general-hospitals. Support the previous researches that the result indicated that organizational justice perception had a significant relationship with organizational commitment and turnover intentions.

Considering that the nurses' ethical leadership, organizational justice and turnover intention scale and sub-dimension scores were evaluated over 5 , the total score of the organizational justice scale was $3.59 \pm 0.76$, the mean score of the interaction justice sub-dimension was $3,14 \pm 0.87$, the mean score of the procedural justice sub-dimension was $3.96 \pm 0.92$, and the mean score of the distribution justice was $3.99 \pm 0.97$. The most common difficulties nurses face in their work life are role ambiguity, perceived organizational support, and perceived low organizational justice (Huang et al., 2019). Considering that the highest mean score of the turnover intention scale was 14 , and the highest score was $6.96 \pm 2.85$ in our study. It is difficult to handle some of the costs in monetary terms such as the low level of commitment to work in the organization, disruption of daily work, emotional stress and excessive workload on the rest. The number of staff leaving the job may have a negative outlook both inside and outside the organization (Singh \& Loncar, 2010).

When ethical leadership, organizational justice, and turnover intention according to some individual and professional characteristics of nurses are examined, there was a significant difference in nurses' procedural justice and distribution justice, which are sub-dimensions of 
organizational justice, and turnover intention according to marital status $(\mathrm{p}<0.05)$. Brooks and Zeitz (1999) found that in the study involving 507 nurses in twelve hospitals, the perceived justice mediated the commitment to the organization and the intention to remain as an employee. When employees perceive that decisions at the workplace are taken using fair and egalitarian procedures, it seems that they feel more attached to the organization. There was a linear negative intermediate level relationship between the age of the nurses and the process justice and distribution justice which are sub-dimensions of organizational justice scale $(\mathrm{p}<0.001)$. Concerning the job duration of the nurses, there was a significant difference in terms of distribution justice scores from the sub-dimensions of organizational justice scale $(\mathrm{K}=62,338 \mathrm{p}<0.001)$ and turnover intention scale $(\mathrm{K}=17,314 \mathrm{p}=0.002)$. Individual factors provide evidence for small but stable relationships between marital status, education and turnover intention. Some studies have suggested that older nurses who are married and have lower education work are more stable in their jobs ( Yin \& Yang, 2002).

When correlations between scales are examined in the study, there was a strong linear positive relationship between organizational justice and ethical leadership $(r=0,767 \mathrm{p}<0,05)$. In the study conducted on 285 nurses in an education and research hospital in İzmir, Özden et al (Özden, Arslan, Ertuğrul, \& Karakaya, 2019) stated that there was a significant positive relationship between the nurses' mean scores for the ethical climate, ethical leadership and job satisfaction, and that the nurses' ethical leadership perceptions were affected by their educational status, workplaces and service periods. It has been demonstrated that there is a positive correlation between the perception of organizational justice of health workers and quality performance (Mohamed, 2014). Organizational justice is also a structure that defines the quality of social interaction in the workplace (Greenberg, 1990).

There was a linear negative medium level relationship between organizational justice and turnover intention $(\mathrm{r}=-0.494 \mathrm{p}<0.05)$. Reasons for turnover include mobbing, negative work environments and low organizational justice (Köksal, 2018). There is a linear negative relationship between the ethical leadership scale and the turnover intention scale $(r=-0,403$ $\mathrm{p}<0.05)$. Ethical leadership behavior has found to be led to many positive outcomes such as employee performance, trust in the leader, inner motivation, job satisfaction and emotional commitment (Cheng et al., 2014). Leaders are expected to satisfy employees and prevent stress and dissatisfaction from the environment. Therefore, it is essential to use an effective and harmonious leadership style for the nursing population which constitutes a large working 
group in hospitals. Many studies have shown that the ethical behavior of the leader leads to positive results such as an increase in function quality, and a decrease in turnover and professional stress, and most importantly, increase job satisfaction (Kim \& Brymer, 2011; $\underline{\mathrm{Zhu}, 2008)}$.

The low level of commitment to work in nurses can negatively affect an institution's capacity to meet patient needs and provide quality nursing care. The increase in the number of nurses turnover may disrupt the morale of the nurses in the unit, while also reduce their efficiency (Hayes et al., 2006).

\section{CONCLUSION}

Leadership, organizational justice, identification and commitment in the field of organizational theory and organizational behavior have been important concepts and research areas. Nurses are the most important component of healthcare delivery programs and patient care functions. Therefore, there is a lack and gap of empirical study related to the relationship between organizational behavior factors in the field of health care.

Therefore, in this study, the possible effect of the attitudes on ethical leadership and organizational justice factors of nurses on turnover intention was investigated to bridge this gap in the current literature from the medical organization hospital perspective. Results showed that nurses' perception of ethical leadership and justice is an important determinant of decisions to keep or leave their jobs in the organizations. These findings are in line with the studies in the literature, which state that the perception of justice will greatly affect the turnover.

The growth and development in the fields of nurses, which is the largest group of staff providing health services, is also important for the health institution to achieve professional success. The result of this study indicated that ethical leadership will increase the perception of justice in the organization and decrease the turnover. The ethical leadership behaviors exhibited by the managers increase productivity and job satisfaction and provide a basis for reducing turnover. 
According to the results of the research, strengthening the organizational justice and ethical leadership perceptions of nursing staff can further improve their commitment to work and reduce their turnover intention. Such a relationship in the research literature related to nurses in Turkey is almost never discussed. The present study confirms the argument that hospital human resource management should focus on behavioral variables that improve such organizational commitment-enhancing attitudes to increase efficiency and performance.

\section{REFERENCES}

Barkhordari-Sharifabad, M., Ashktorab, T., \& Atashzadeh-Shoorideh, F. (2017). Exploration of pioneering as a major element of ethical leadership in nursing: a qualitative study. Electronic physician, 9(7), 4737.

Brockner, J., Konovsky, M., Cooper-Schneider, R., Folger, R., Martin, C., \& Bies, R. J. (1994). Interactive effects of procedural justice and outcome negativity on victims and survivors of job loss. Academy of management Journal, 37(2), 397-409.

Brooks, A., \& Zeitz, G. (1999). The effects of total quality management and perceived justice on organizational commitment of hospital nursing staff. Journal of Quality Management, 4(1), 69-93.

Brown, M. E., Treviño, L. K., \& Harrison, D. A. (2005). Ethical leadership: A social learning perspective for construct development and testing. Organizational behavior and human decision processes, 97(2), 117-134.

Cao, Y., Liu, J., Liu, K., Yang, M., \& Liu, Y. (2019). The mediating role of organizational commitment between calling and work engagement of nurses: A cross-sectional study. International journal of nursing sciences, 6(3), 309-314.

Cheng, J.-W., Chang, S.-C., Kuo, J.-H., \& Cheung, Y.-H. (2014). Ethical leadership, work engagement, and voice behavior. Industrial Management \& Data Systems, 114(5), 817-831.

Colquitt, J. A., Conlon, D. E., Wesson, M. J., Porter, C. O., \& Ng, K. Y. (2001). Justice at the millennium: a meta-analytic review of 25 years of organizational justice research. Journal of applied psychology, 86(3), 425.

Elovainio, M., van den Bos, K., Linna, A., Kivimäki, M., Ala-Mursula, L., Pentti, J., \& Vahtera, J. (2005). Combined effects of uncertainty and organizational justice on employee health: testing the uncertainty management model of fairness judgments among Finnish public sector employees. Social Science \& Medicine, 61(12), 25012512. 
Gagné, M., \& Deci, E. L. (2005). Self-determination theory and work motivation. Journal of Organizational behavior, 26(4), 331-362.

Gillet, N., Fouquereau, E., Coillot, H., Bonnetain, F., Dupont, S., Moret, L., . . . Colombat, P. (2018). Ethical leadership, professional caregivers' well-being, and patients' perceptions of quality of care in oncology. European Journal of Oncology Nursing, $33,1-7$.

Greenberg, J. (1990). Organizational justice: Yesterday, today, and tomorrow. Journal of management, 16(2), 399-432.

Hayes, L. J., O’Brien-Pallas, L., Duffield, C., Shamian, J., Buchan, J., Hughes, F., . . Stone, P. W. (2006). Nurse turnover: a literature review. International journal of nursing studies, 43(2), 237-263.

Hayward, D., Bungay, V., Wolff, A. C., \& MacDonald, V. (2016). A qualitative study of experienced nurses' voluntary turnover: learning from their perspectives. Journal of clinical nursing, 25(9-10), 1336-1345.

Heponiemi, T., Elovainio, M., Laine, J., Pekkarinen, L., Eccles, M., Noro, A., . . Sinervo, T. (2007). Productivity and employees' organizational justice perceptions in long-term care for the elderly. Research in nursing \& health, 30(5), 498-507.

Holtom, B. C., Mitchell, T. R., Lee, T. W., \& Eberly, M. B. (2008). 5 turnover and retention research: a glance at the past, a closer review of the present, and a venture into the future. The Academy of Management Annals, 2(1), 231-274.

Huang, X., Li, Z., \& Wan, Q. (2019). From organisational justice to turnover intention among community nurses: A mediating model. Journal of clinical nursing, 28(21-22), 39573965 .

Imamoglu, S. Z., Ince, H., Turkcan, H., \& Atakay, B. (2019). The Effect of Organizational Justice and Organizational Commitment on Knowledge Sharing and Firm Performance. Procedia Computer Science, 158, 899-906.

Islam, T., Ahmed, I., \& Ali, G. (2019). Effects of ethical leadership on bullying and voice behavior among nurses. Leadership in Health Services.

Jawahar, I. (2002). A model of organizational justice and workplace aggression. Journal of management, 28(6), 811-834.

Kim, W. G., \& Brymer, R. A. (2011). The effects of ethical leadership on manager job satisfaction, commitment, behavioral outcomes, and firm performance. International Journal of Hospitality Management, 30(4), 1020-1026.

Köksal, K. (2018). Örgüt Kültürünün Örgütsel Adalet Algısına Etkisinde Etik İlkelere İlişkin Algıların Aracılık Rolü. Uluslararası Yönetim İktisat ve İşletme Dergisi, 14(2), 479504. 
Loi, R., Yang, J., \& Diefendorff, J. M. (2009). Four-factor justice and daily job satisfaction: a multilevel investigation. Journal of applied psychology, 94(3), 770.

Mimaroğlu, H. (2008). Psikolojik sözleşmenin personelin tutum ve davranışlarına etkileri: Tıbbi satış temsilcileri üzerinde bir araştırma. Basılmamış Doktora Tezi, Çukurova Üniversitesi Sosyal Bilimler Enstitüsü.

Mohamed, S. A. (2014). The relationship between organizational justice and quality performance among healthcare workers: a pilot study. The Scientific World Journal, 2014.

Niehoff, B. P., \& Moorman, R. H. (1993). Justice as a mediator of the relationship between methods of monitoring and organizational citizenship behavior. Academy of management Journal, 36(3), 527-556.

Özden, D., Arslan, G. G., Ertuğrul, B., \& Karakaya, S. (2019). The effect of nurses' ethical leadership and ethical climate perceptions on job satisfaction. Nursing ethics, 26(4), 1211-1225.

Polat, S. (2007). Ortaöğretim öğretmenlerinin örgütsel adalet algılart, örgütsel güven düzeyleri ile örgütsel vatandaşlık davranışları arasındaki ilişki. (PhD Unpublished). Kocaeli Üniversitesi, Retrieved from http://dspace.kocaeli.edu.tr:8080/xmlui/handle/11493/399

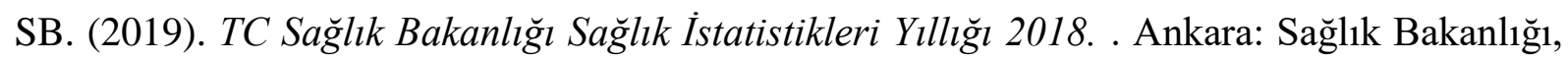
Sağlık Bilgi Sistemleri Genel Müdürlüğü.

Seashore, S. E., Lawler III, E. E., Mirvis, P. H., \& Cammann, C. E. (1983). Assessing organizational change: A guide to methods, measures, and practices: John Wiley \& Sons Inc.

Singh, P., \& Loncar, N. (2010). Pay satisfaction, job satisfaction and turnover intent. Relations industrielles/industrial relations, 65(3), 470-490.

Staggs, V. S., \& Dunton, N. (2012). Hospital and unit characteristics associated with nursing turnover include skill mix but not staffing level: an observational cross-sectional study. International journal of nursing studies, 49(9), 1138-1145.

Tummers, L. G., Groeneveld, S. M., \& Lankhaar, M. (2013). Why do nurses intend to leave their organization? A large-scale analysis in long-term care. Journal of advanced nursing, 69(12), 2826-2838.

Tuna, M., Bircan, H., \& Yeşiltaş, M. (2012). Etik liderlik ölçeği’nin geçerlilik ve güvenilirlik çalişmasi: antalya örneği. Atatürk Üniversitesi İktisadi ve İdari Bilimler Dergisi, 26(2), 143-155.

Yin, J.-C. T., \& Yang, K.-P. A. (2002). Nursing turnover in Taiwan: a meta-analysis of related factors. International journal of nursing studies, 39(6), 573-581. 
Zhang, N., Li, M., Gong, Z., \& Xu, D. (2019). Effects of ethical leadership on nurses' service behaviors. Nursing ethics, 26(6), 1861-1872.

Zhu, W. (2008). The effect of ethical leadership on follower moral identity: The mediating role of psychological empowerment. Leadership Review, 8(3), 62-73. 